\title{
Knowledge and management of fever among Moroccan parents
}

\author{
M. Rkain, ${ }^{1}$ I. Rkain, ${ }^{2}$ M. Safi, ${ }^{7}$ M. Kabiri, ${ }^{3}$ S. Ahid ${ }^{2,4}$ and B.D.S. Benjelloun ${ }^{7}$
}

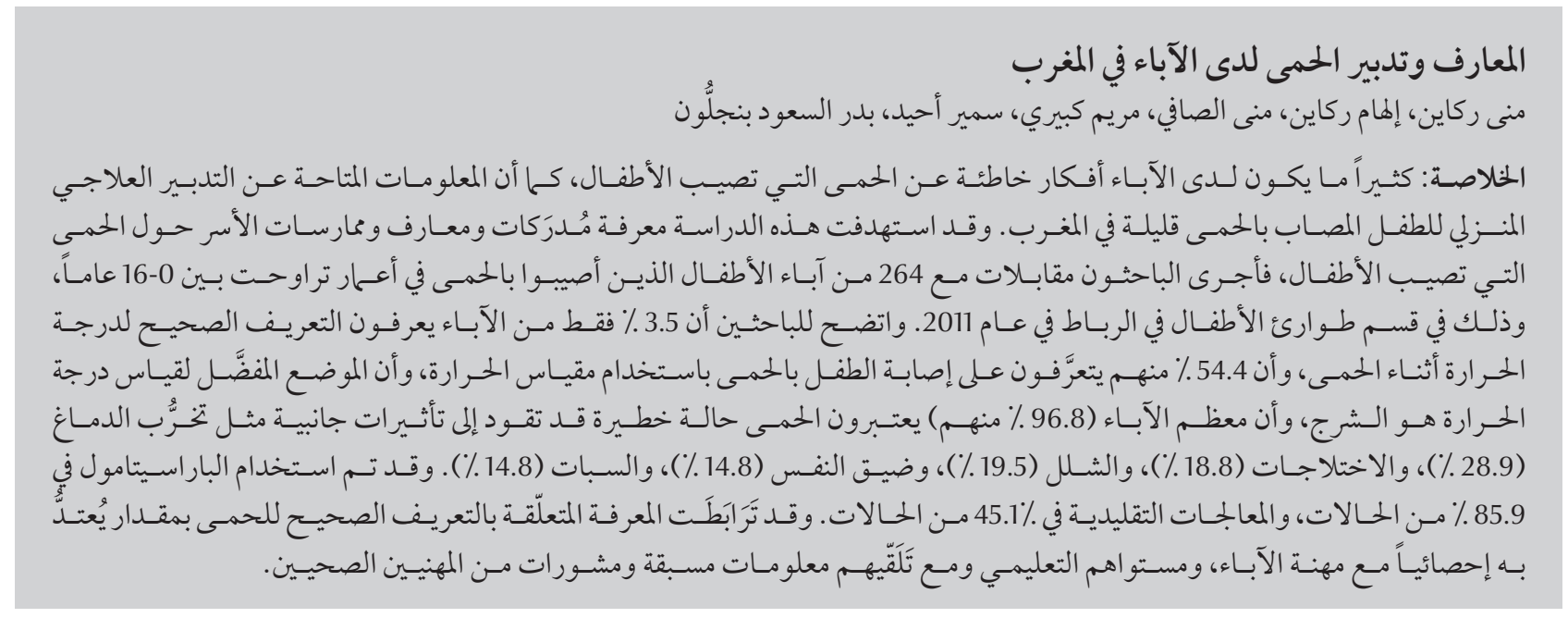

ABSTRACT Parents often have misperceptions about childhood fever, and little information is available about the home management of feverish children in Morocco. In this study of the perceptions, knowledge and practices of families regarding children's fever, the parents of 264 febrile children aged 0-16 years were interviewed in a paediatric emergency department in Rabat in 2011. Only 3.5\% of parents knew the correct temperature definition for fever, 54.4\% determined their children's fever using a thermometer, and the preferred site was rectal. Most of them (96.8\%) considered that fever was a very serious condition, which could lead to side-effects such as brain damage (28.9\%), seizures (18.8\%) paralysis (19.5\%), dyspnoea (14.8\%) and coma (14.8\%). Paracetamol was used by $85.9 \%$ and traditional treatments by $45.1 \%$. Knowledge about the correct definition of fever was significantly associated with parents' profession, educational level and receipt of previous information and advice from health professionals.

\section{Épisode fébrile chez l'enfant : connaissances des parents marocains et prise en charge par ces derniers}

RÉSUMÉ Les parents ont souvent des perceptions erronées concernant la fièvre chez l'enfant, et les informations sur la prise en charge des enfants fébriles à domicile sont rares au Maroc. Dans la présente étude sur les perceptions, les connaissances et les pratiques des familles au sujet de la fièvre chez l'enfant, les parents de 264 enfants fébriles âgés de 0 à 16 ans ont été interrogés au sein d'un service d'urgence pédiatrique de la ville de Rabat en 2011. Seuls 3,5\% des parents connaissaient la température exacte définissant un état fébrile et 54,4\% déterminaient la fièvre de leur enfant à l'aide d'un thermomètre, de préférence par voie rectale. La plupart d'entre eux $(96,8 \%)$ considéraient que la fièvre était une affection très grave qui pouvait conduire à des effets secondaires tels que des lésions cérébrales (28,9\%), des convulsions (18,8\%), une paralysie (19,5\%), une dyspnée $(14,8 \%)$ et un coma (14,8\%). Le paracétamol a été utilisé par 85,9\% des parents et les traitements traditionnels par 45,1\%. La connaissance de la définition exacte de la fièvre était significativement associée à la profession des parents, à leur niveau d'études et à la prise de conseils et d'informations préalable auprès des professionnels de santé. 


\section{Introduction}

Fever is one of the most common presenting complaints in paediatrics and general practice and is the cause of nearly $70 \%$ of all paediatric visits (1). A number of studies have investigated parents' knowledge, perceptions, theories and practices of childhood fever (2-5). Parents frequently perceive fever as a disease rather than as a symptom or sign of illness (2), as defined by Schmitt in 1980 who introduced the term "fever phobia" to describe parents' fearful view of fever (3). Insufficient knowledge of parents concerning the cause of fever, and misconceptions about its effects on their children's health frequently lead to excessive fear and anxiety (4). A frequent finding is that parents are not correctly informed about temperature, defining fever as a medical term (6-8).

Impicciatore et al. studying mothers' perceptions and attitudes towards fever and its treatment found that most mothers did not know how to manage fever (9). Two studies in Greece reached to the same conclusions; Anagnostakis et al. found that parents had incorrect perceptions about fever and worried about temperatures that were considered normal (10), while Mathioudakis et al. found that only $1.4 \%$ of parents correctly evaluated and treated fever and $64.6 \%$ used the wrong dosages of antipyretics (11). Studies further show that educational level, socioeconomic status and cultural background are the main determinants of knowledge and judgement of childhood fever (12,13). A higher socioeconomic status and educational level contributed to a more scientifically oriented knowledge of fever.

Little information is available about the home management of feverish children in Morocco; in particular, no studies have been published on parents' knowledge, perceptions and attitudes regarding fever in their children. The aim of our study was to reveal the perceptions, knowledge and practices of families regarding childhood fever and to discuss the differences between our population and other populations.

\section{Methods}

\section{Study sample}

This study participants were a convenience sample of parents of children aged $0-16$ years attending the paediatric emergency department during 4 months from July to October 2011. Only the parents were asked to participate in the study. All of the parents who we approached agreed to be in the study and none were excluded.

\section{Data collection}

On arrival at the department, the parents of the child were asked to answer to a questionnaire while waiting for examination of the child. The parents were informed about the study, reassured about the confidentiality of data and their right to refuse participation without any consequences for the treatment of their children and requested to verbally consent to participation.

The parents were interviewed using face-to-face interviews in Moroccan Arabic. The interviews, which were conducted in a separate room of the department in order to guarantee privacy, lasted approximately 20 minutes. One physician read questions to the participant from a questionnaire and the parents were given no assistance with answering the questions. The participants were asked open-ended yes/no and multiple-choice questions about sociodemographic data and their knowledge (4 items), beliefs (4 items) and practices (11 items) concerning fever. Parents were also asked if they had received advice or general information in the past from physicians, pharmacists, nurses or parents regarding the management of fever. A temperature of $38^{\circ} \mathrm{C}$ or above was considered to indicate fever (14).

\section{Data analysis}

Statistical analyses were performed using SPSS, version 13.0. Data were presented as percentages and means and standard deviation (SD). Statistical significance was determined by the Pearson test. A value of $P<0.05$ was considered significant. All variables were coded as dummy variables. In univariate analysis, a logistic regression model was used to search for factors that influenced parents' knowledge about the definition of fever temperature and their practices regarding fever and to calculate their odds ratios (OR) and 95\% confidence intervals (CI). Variables with $P<0.25$ were entered into the multivariate analysis

\section{Results}

The total number of parents interviewed was 264 . The mean age of parents was 31.6 (SD 8.5) years and most of them $(81.0 \%)$ were mothers. The sociodemographic characteristics of parents are summarized in Table 1. A majority resided in urban areas (88.6\%).

Only $3.5 \%$ of the parents knew the correct temperature definition for fever. Just over half the parents (54.4\%) determined their children's fever using a thermometer, while $44.4 \%$ stated that fever could be determined by touching the child's forehead. Of the parents, $58.9 \%$ could read the thermometer. The preferred route of measuring temperature was rectal (Table 2). In our study, $96.8 \%$ of parents considered that fever was a very serious condition, which could lead to side-effects such as brain damage (28.9\%), seizures (18.8\%), paralysis (19.5\%), breathing difficulty (14.8\%) and coma (14.8\%) (Table 2).

When fever persisted, $85.7 \%$ of parents consulted the general practitioner (39.9\%) or paediatrician (45.8\%). Of all the parents, $72.0 \%$ had received no information about fever and $47.3 \%$ 


\begin{tabular}{|c|c|c|c|c|}
\hline Variable & & & Correct kno & definition of \\
\hline Mean (SD) age (years) & & & & \\
\hline Mean (SD) no. of children & & & & \\
\hline & No. & $\%$ & No. & $\%$ \\
\hline Socioeconomic level & & & & \\
\hline Low & 57 & 21.6 & 4 & 6.9 \\
\hline Middle & 192 & 72.7 & 44 & 75.9 \\
\hline High & 15 & 5.7 & 10 & 17.2 \\
\hline Educational level & & & & \\
\hline Illiterate & 92 & 35.0 & 9 & 15.8 \\
\hline Primary school & 58 & 22.1 & 6 & 10.5 \\
\hline High school & 59 & 22.4 & 17 & 29.8 \\
\hline University & 54 & 20.5 & 25 & 43.9 \\
\hline Profession & & & & \\
\hline Not working & 159 & 60.9 & 28 & 50.0 \\
\hline Retired & 1 & 0.4 & 0 & 0.0 \\
\hline Private sector & 54 & 20.7 & 8 & 14.3 \\
\hline Public sector & 47 & 18.0 & 20 & 35.7 \\
\hline Place of residence & & & & \\
\hline Urban & 234 & 88.6 & 58 & 100.0 \\
\hline Rural & 30 & 11.4 & 0 & 0.0 \\
\hline Received general informat & & & & \\
\hline Yes & 191 & 72.6 & 22 & 38.6 \\
\hline No & 72 & 27.4 & 35 & 61.4 \\
\hline Received advice about feve & & & & \\
\hline Yes & 139 & 52.7 & 13 & 22.4 \\
\hline No & 125 & 47.3 & 45 & 77.6 \\
\hline
\end{tabular}

$S D=$ standard deviation .

had received advice on management of a feverish state for their children. The source of information was mainly from a paediatrician $(23.5 \%)$, general practitioner $(21.2 \%)$ or the experience of grandparents (16.3\%). The parents' interventions for their children's fever are shown in Table 3. Paracetamol was used by $85.9 \%$ of parents and traditional treatments by $45.1 \%$.

Table 1 shows the demographic characteristics and receipt of information/advice of those with correct knowledge about the definition of fever temperature, while Table 4 shows the univariate and multivariate analysis of the data. Variables which did not significantly affect knowledge about their definition of fever were age $(P=$ $0.059)$, sex $(P=0.241)$, place of residence (urban/rural) $(P=0.998)$ and number of children in the family $(P=$ 0.415). Higher socioeconomic level was associated with better knowledge about the definition of fever in the univariate $(P<0.001)$ but not in the multivariate analysis $(P=0.453)$. In multivariate analysis, parents' educational level $(P<0.001)$, profession $(P$ $=0.016)$, and previous information $(P$ $=0.007)$ and advice about fever $(P=$ 0.007 ) were significantly associated with knowledge regarding the definition of fever (Table 4).

\section{Discussion}

The present study is an analysis of Moroccan parents' perceptions, knowledge and interventions about fever. Half of the parents in this study were highschool graduates. Most of the parents were assumed to be socioeconomically relatively advantaged because our emergency department is located in the capital city.

The use of a thermometer is the only way to determine whether a child is febrile. All other methods including tactile and visual assessment are inaccurate (6); for example, it has been shown that touching the forehead detected only 


\begin{tabular}{|c|c|c|}
\hline Characteristic & No. & $\begin{array}{c}\% \\
(n=264)\end{array}$ \\
\hline \multicolumn{3}{|c|}{ Definition offever temperature $\left({ }^{\circ} \mathrm{C}\right)$} \\
\hline $38-<38.5$ & 9 & 3.5 \\
\hline$<38$ or $>38.5$ & 162 & 61.3 \\
\hline Don't know & 93 & 35.2 \\
\hline \multicolumn{3}{|c|}{ Way of measuring child's temperature } \\
\hline Thermometer & 143 & 54.4 \\
\hline Touching the forehead & 117 & 44.5 \\
\hline Chills & 5 & 0.8 \\
\hline If the child drinks a lot & 1 & 0.4 \\
\hline \multicolumn{3}{|c|}{ Has a thermometer at home } \\
\hline Yes & 161 & 61.2 \\
\hline No & 102 & 38.8 \\
\hline \multicolumn{3}{|c|}{ Type of thermometer used to take child's temperature } \\
\hline Rectum & 126 & 73.7 \\
\hline Armpit & 43 & 25.1 \\
\hline Ear & 2 & 1.2 \\
\hline \multicolumn{3}{|l|}{ Can read the thermometer } \\
\hline Yes & 142 & 58.9 \\
\hline No & 99 & 41.1 \\
\hline \multicolumn{3}{|l|}{ Believe fever has a purpose } \\
\hline Yes & 8 & 3.1 \\
\hline No & 246 & 96.9 \\
\hline \multicolumn{3}{|l|}{ Believe fever is dangerous } \\
\hline Yes & 153 & 59.5 \\
\hline No & 104 & 40.5 \\
\hline \multicolumn{3}{|l|}{ Dangers specified } \\
\hline Neurological & 43 & 28.9 \\
\hline Seizures & 28 & 18.8 \\
\hline Paralysis & 29 & 19.5 \\
\hline Breathing difficulty & 22 & 14.8 \\
\hline Coma & 22 & 14.8 \\
\hline Death & 4 & 2.7 \\
\hline Blindness & 1 & 0.7 \\
\hline
\end{tabular}

$74 \%$ of all febrile children (15). In the our study, $54.4 \%$ of the parents used a thermometer to detect their children's fever, but nearly half of them detected fever by touching the children's forehead, which is frequently considered by parents to be the most accurate way of measuring an infant's temperature (16).

Axillary temperatures are adequate for clinical screening or fever (15). In our study, three-quarters of parents preferred the rectal route for temperature
In the present study, $96.5 \%$ of the parents stated the incorrect temperature or did not know the correct temperature for fever. This was similar to the findings of previous reports in culturally diverse populations in different countries $(6,7$, $17,19)$. The parents with higher educational level demonstrated a significantly higher rate of accuracy in their knowledge of fever definition in our study $(P=$ $0.001)$, in accordance with the findings of previous studies conducted among different populations (20-22).

In our study the majority of parents used paracetamol as an antipyretic in treating children's fever, corroborating the findings of studies in other populations $(6,7,17)$. Aspirin and ibuprofen were not preferred in our study sample. In our hospital, we frequently inform parents about the risks of aspirin use in febrile children (such as Reye syndrome and gastrointestinal bleeding). These could be the reasons why the parents in the present study preferred paracetamol as an antipyretic. In our Moroccan traditions, iced water is not used as a method of lowering the temperature, while other methods are practised such as towels soaked in cold water.

Nearly $60 \%$ of the parents in our study believed that fever could have dangerous effects on children, even death. Of all the parents, $28.9 \%$ listed brain damage as the most common harmful effect of fever, $18.8 \%$ seizures, $19.5 \%$ paralysis and $14.8 \%$ coma. In the literature, it was reported that many of these beliefs are also shared by paediatric health care providers (12) and fever phobia was the message that they conveyed to parents (21).

Parental educational status showed a significant effect on the parents' interventions and knowledge about fever, a finding which corroborates other studies from different populations $(6,17,20$, $23,24)$. In our study, parents who had received advice from their doctor and therefore had more information than those who had not had advice, knew better how to manage their febrile children. 


\begin{tabular}{|c|c|c|}
\hline Variable & No. & $\begin{array}{c}\% \\
(n=264)\end{array}$ \\
\hline \multicolumn{3}{|c|}{ Physical measures } \\
\hline Bath & 80 & 46.8 \\
\hline Undressing & 36 & 21.1 \\
\hline Drinks & 27 & 15.8 \\
\hline Wet towels & 28 & 16.4 \\
\hline \multicolumn{3}{|l|}{ Antipyretics } \\
\hline Paracetamol & 213 & 85.9 \\
\hline Aspirin & 22 & 8.9 \\
\hline Ibuprofen & 13 & 5.2 \\
\hline \multicolumn{3}{|c|}{ Route of administration of antipyretics } \\
\hline Rectal & 154 & 64.2 \\
\hline Oral & 86 & 35.8 \\
\hline \multicolumn{3}{|c|}{ Traditional treatments } \\
\hline Rosewater & 65 & 45.1 \\
\hline Vinegar & 23 & 16.0 \\
\hline Lemon & 11 & 7.6 \\
\hline Anserine $^{\mathrm{a}}$ & 45 & 31.3 \\
\hline
\end{tabular}

${ }^{a}$ Chenopodium ambrosioides (wormseed).

\begin{tabular}{|c|c|c|c|c|c|c|}
\hline \multirow[t]{2}{*}{ Variable } & \multicolumn{3}{|c|}{ Univariate analysis } & \multicolumn{3}{|c|}{ Multivariate analysis } \\
\hline & OR & $(95 \% \mathrm{CI})$ & $P$-value & OR & $(95 \% \mathrm{CI})$ & $P$-value \\
\hline Age & 1.03 & $(1.00-1.07)$ & 0.059 & $\mathrm{n} / \mathrm{a}$ & - & - \\
\hline Sex & 0.67 & $(0.34-1.32)$ & 0.241 & 1.01 & $(0.96-1.06)$ & 0.803 \\
\hline Educational level & 2.19 & $(1.60-2.84)$ & $<0.001$ & 2.36 & $(1.45-3.85)$ & 0.001 \\
\hline Profession & 1.37 & $(1.09-1.73)$ & 0.007 & 0.60 & $(0.40-0.91)$ & 0.016 \\
\hline Socioeconomic level & 5.16 & $(2.41-11.1)$ & $<0.001$ & 1.47 & $(0.54-4.02)$ & 0.453 \\
\hline Place of residence & 0.00 & 0.00 & 0.998 & $\mathrm{n} / \mathrm{a}$ & - & - \\
\hline Received general information & 7.27 & (3.83-13.8) & $<0.001$ & 3.23 & $(1.39-7.55)$ & 0.007 \\
\hline Received advice & 5.45 & $(2.77-10.7)$ & $<0.001$ & 3.24 & $(1.38-7.60)$ & 0.007 \\
\hline No. of children & 0.90 & $(0.73-1.14)$ & 0.415 & $\mathrm{n} / \mathrm{a}$ & - & - \\
\hline
\end{tabular}

$O R=$ odds ratio $; C I=$ confidence interval $n / a=$ not applicable.

One limitation of the present study was that data were collected from parents presenting to one emergency department. Therefore the findings might not be generalizable to the Moroccan population. Multi-centre trials may show differences in trends and provide useful comparisons.

Competing interests: None declared.

\section{References}

1. Figueras Nadal C, García de Miguel MJ, Gómez Campderá A, Pou Fernández J, Alvarez Calatayud G, Sánchez Bayle M; Paediatric Fever Co-operative Group from the Spanish Paediatric Association. Effectiveness and tolerability of ibuprofen-arginine versus paracetamol in children with fever of likely infectious origin. Acta Paediatr. 2002;91(4):383-90. PMID:12061352
2. What worries parents when their preschool children are acutely ill, and why: a qualitative study. BMJ. 1996;313(7063):983-6. PMID:8892420

3. Crocetti M, Moghbeli N, Serwint J. Fever phobia revisited: have parental misconceptions about fever changed in 20 years? Pediatrics. 2001 Jun;107(6):1241-6. PMID:11389237 
4. Rideout ME, First LR. Fever: measuring and managing a sizzling symptom. Contemp Pediatr. 2001;18:42-50.

5. Purssell E. Parental fever phobia and its evolutionary correlates. J Clin Nurs. 2009 Jan;18(2):210-8. PMID:18298501

6. Taveras EM, Durousseau S, Flores G. Parents' beliefs and practices regarding childhood fever: a study of a multiethnic and socioeconomically diverse sample of parents. Pediatr Emerg Care. 2004 Sep;20(9):579-87. PMID:15599258

7. Blumenthal I. What parents think of fever. Fam Pract. 1998 Dec;15(6):513-8. PMID:10078789

8. Krantz C. Childhood fevers: developing an evidence-based anticipatory guidance tool for parents. Pediatr Nurs. 2001 NovDec;27(6):567-71. PMID:12024528

9. Impicciatore $\mathrm{P}$, Violante $\mathrm{A}$, Bonati M. Helping parents to cope when their preschool children are acutely ill. Educationa interventions may defuse parents' concern. BMJ. 1997 Feb 1;314(7077):373. PMID:9040350

10. Kallestrup P, Bro F. Parents' beliefs and expectations when presenting with a febrile child at an out-of-hours general practice clinic. Br J Gen Pract. 2003 Jan;53(486):43-4. PMID:12564276

11. Walsh A, Edwards H, Fraser J. Parents' childhood fever management: community survey and instrument development. J Adv Nurs. 2008 Aug;63(4):376-88. PMID:18727765

12. Crocetti M, Moghbeli N, Serwint J. Fever phobia revisited: have parental misconceptions about fever changed in 20 years? Pediatrics. 2001 Jun;107(6):1241-6. PMID:11389237

13. Walsh A, Edwards H. Management of childhood fever by parents: literature review. J Adv Nurs. 2006 Apr;54(2):217-27. PMID:16553708

14. Gal P, Reed MD. Medications. In: Behrman RE, Kleigman RM, Jenson HB, editors. Nelson textbook of pediatrics. 17th ed. Philadelphia (Pennsylvania): WB Saunders; 2004. pp. 2432-501.
15. Schmitt BD. Fever in childhood. Pediatrics. 1984 Nov;74(5 Pt 2):929-36. PMID:6333668

16. Fallis WM, Brunsdon-Clark B, Andries A, Gilbert E. A parent's response prompts a search for current trends in taking the temperature of pediatric ED patients. J Emerg Nurs. 2005 Oct;31(5):462-4. PMID:16198730

17. al-Eissa YA, al-Zamil FA, al-Sanie AM, al-Salloum AA, al-Tuwaijri HM, al-Abdali NM, et al. Home management of fever in children: rational or ritual? Int J Clin Pract. 2000 Apr;54(3):138-42. PMID:10829354.

18. Kai J. Parents' perceptions of taking babies' rectal temperature. BMJ. 1993 Sep 11;307(6905):660-2. PMID:8401054

19. Parmar RC, Sahu DR, Bavdekar SB. Knowledge, attitude and practices of parents of children with febrile convulsion. J Postgrad Med. 2001 Jan-Mar;47(1):19-23. PMID:11590285

20. Al-Nouri L, Basheer K. Mothers' perceptions of fever in children. J Trop Pediatr. 2006 Apr;52(2):113-6, discussion 117. PMID:16115838

21. Crocetti M, Sabath B, Cranmer L, Gubser S, Dooley D. Knowledge and management of fever among Latino parents. Clin Pediatr (Phila). 2009 Mar;48(2):183-9. PMID:18840888

22. Walsh A, Edwards H, Fraser J. Parents' childhood fever management: community survey and instrument development. J Adv Nurs. 2008 Aug;63(4):376-88. PMID:18727765

23. Mackowiak PA. Concepts of fever. Arch Intern Med. 1998 Sep 28;158(17):1870-81. PMID:9759682

24. Poirier MP, Collins EP, McGuire E. Fever phobia: a survey of caregivers of children seen in a pediatric emergency department. Clin Pediatr (Phila). 2010 Jun;49(6):530-4. PMID:20488812 